Summer 2003

\title{
Normative Creativity and Global Legal Pluralism: Reflections on the Democratic Critique of Transnational Law
}

Oren Perez

Bar-Ilan University, Ramat-Gan, Israel

Follow this and additional works at: https://www.repository.law.indiana.edu/ijgls

Part of the International Law Commons

\section{Recommended Citation}

Perez, Oren (2003) "Normative Creativity and Global Legal Pluralism: Reflections on the Democratic Critique of Transnational Law," Indiana Journal of Global Legal Studies: Vol. 10 : Iss. 2 , Article 2. Available at: https://www.repository.law.indiana.edu/ijgls/vol10/iss2/2

This Article is brought to you for free and open access by the Law School Journals at Digital Repository @ Maurer Law. It has been accepted for inclusion in Indiana Journal of Global Legal Studies by an authorized editor of Digital Repository @ Maurer Law. For more information, please contact rvaughan@indiana.edu.

\section{$\Psi$}

JEROME HALL LAW LIBRARY

INDIANA UNIVERSITY

Maurer School of Law
Bloomineton 


\title{
Normative Creativity and Global Legal Pluralism: Reflections on the Democratic Critique of Transnational Law
}

\author{
Oren Perez
}

The globalization process has changed the nature of the "social." Social interactions have become much more varied and flexible-transgressing traditional political and cultural boundaries (and expectations). The emergence of new forms of global law, which evolve and operate across these traditional lines, is a major aspect of globalization. 'This expanding network of transnational "legalities" is not based on a coherent set of normative or institutional hierarchies. Rather, it represents a highly pluralistic mixture of legal regimes, with variable organizational and thematic structures: from state-oriented systems-such as the dispute settlement system of the WTO, or the adjudicative system of the Law of the Sea Convention-to hybrid ${ }^{2}$ or private regimes. The latter category includes, for example, the expanding field of technical standardization, ${ }^{3}$ the new governance structure of the Internet, ${ }^{4}$ and the field of transnational arbitration. ${ }^{5}$

* Faculty of Law, Bar-Ilan University, Ramat-Gan, Israel. In preparing this article I benefited from the comments of the participants at the Conference on Social Movements and New Social Communities: North/South Globalization, New York University, April 20-22, 2001, in which an earlier version of this article was delivered. I am grateful to the Florence Unger and Samuel Goldstein, M.D., Interdisciplinary Center for Law, Rationality, Ethics and Social Justice for financial support.

1. See, e.g., Gunther Teubner, 'Global Bukowina': Legal Pluralism in the World Society, in GLOBAL LAW WITHOUT A STATE 3-28 (Gunther Teubner ed., 1997); see also Andrew Linklater, The Evolving Spheres of International Justice, 75 INT'L AFF. 473 (1999); Sol Picciotto, Networks in International Economic Integration: Fragmented States and the Dilemmas of Neo-Liberalism, 17 NW. J. INT'L. L. \& BUS. 1014 (1996).

2. The term "hybrid" refers to the tight cooperation between public and private bodies in certain regimes.

3. Technical standardization is led and dominated by a variety of transnational organizations such as the International Organization for Standardization, the International Electrotechnical Commission and the Codex Alimentarius Commission.

4. A key player in this new field of governance is the Internet Corporation for Assigned Names and Numbers (ICANN). One of the more prominent achievements in this field was the establishment of an international system for the resolution of domain name controversies. The system was developed jointly by ICANN and the World Intellectual Property Organization (WIPO).

5. Transnational arbitration is dominated by international legal firms (mainly American and European) and business associations such as the International Chamber of Commerce and its International Court of Arbitration. 
The globality of these systems stems from their (parallel) claim for universal validity, and from the cosmopolitan nature of their thematic horizon (which means that their normative effort is directed primarily at global issues). ${ }^{6}$

Many of these new global legal structures have evolved in response to the needs of the global economy, with its adamant push for a system free of regulatory barriers. The normative outlook of these systems, however, is not limited to the economic domain. It has significant spill-overs, with wide-ranging social implications, from environmental to cultural. The influence of these systems over the life of the global citizenry has increased substantially over the last decade. The WTO legal system, for example, has addressed disputes involving difficult environmental dilemmas-from the risks associated with the use of synthetic growth hormones in cattle, to the damage caused to sea turtles by shrimp trawling, to the risks associated with the industrial use of asbestos. ${ }^{7}$ International standards-setting organizations, such as the International Organization for Standardization (ISO) and the Codex Alimentarius Commission, have been involved in the production of controversial standards, such as the ISO environmental management standards (the ISO 14000 series) and the Codex Commission's evolving standards on foods derived from biotechnology. ${ }^{8}$

The affinity of these global legal structures to economic interests has adversely influenced their sensitivity to "civic" concerns and has been subject to extensive criticism in both grass-root and academic circles. ${ }^{9}$ The recent protests

6. See, e.g., Teubner, supra note 1.

7. See Appellate Body Report, EC-Measures Concerning Meat and Meat Products (Hormones), Jan. 16, 1998, WT/DS26/AB/R, WT/DS48/AB/R [hereinafter Hormones Case]; Appellate Body Report, United States-Import Prohibition of Certain Shrimp and Shrimp Products, Oct. 12, 1998, WT/DS58/AB/R [hereinafter Shrimp Report]; Appellate Body Report, EC-Measures Affecting Asbestos and Asbestos-Containing Products, Mar. 12, 2001, WT/DS135/AB/R [hereinafter EC-Asbestos]. The rulings of the WTO tribunals are available at the WTO disputes settlement gateway: http://www.wto.org/english/tratop_e/dispu_e/ dispu_e.htm.

8. The ISO 14000 series is a wide-ranging collection of international, voluntary environmental standards deal with a variety of corporate management issues. For a more detailed discussion, see infra Part $\mathrm{I}$. The Codex Commission is currently trying to develop general principles for risk analysis of foods derived from biotechnology. See, for further details, the Codex Commission Website: http:// www.codexalimentarius.net. The Codex Commission was also involved in other controversial issues such as the risks of administering growth hormones to cattle.

9. See Globalising Poverty, Ecologist ReP., Sept. 2000, at 6 (critiquing the Bretton Woods institutions) [hereinafter Globalising Poverty]; see also Patti Goldman \& Martin Wagner, Trading Away Public Health: WTO Obstacles to Effective Toxic Controls, 20 Multinational Monitor (1999), available at $\mathrm{http} / / \mathrm{multinationalmonitor.org} / \mathrm{mm} 1999 / \mathrm{mm} 9910.08 \mathrm{html}$. For an analysis of the 
against globalization-from Seattle 1998 to Quebec and Gothenburg 2001were driven by a deep skepticism of the legitimacy of these a-national legal structures, and a conviction that their decision-making procedures should undergo deep reform. ${ }^{10}$ What emerges from these protests is a profound aspiration for a "voice"-for greater civic involvement in these global processes of norm production. The critique of this evolving network of legal governance has been fierce. Thus it was argued, for example, that the alliance between the three Bretton Woods institutions (the WTO, the World Bank and the IMF)" and the Multinational Enterprises community is imposing upon the global society a new form of "faceless" tyranny, ${ }^{12}$ which is driven by uncontrollable and (socially) inattentive economic rationality, and is governed by a dubious regime of "unaccountable 'experts' adjudicating behind closed doors." 13

This demand for a voice presents the global community with a difficult dilemma. While it is hard to question the urgency and genuineness of this aspiration, casting the demand for a voice in a coherent theoretical or pragmatic form

controversy surrounding the work of the ISO and the Codex Commission, see Paula C. Murray, Inching Toward Environmental Regulatory Reform-ISO 14000: Much Ado About Nothing Or a Reinvention Tool?, 37 Aм. Bus. L. J., 35 (1999). See also George Gaskell et al., World Apart? The Reception of Genetically Modified Foods in Europe and the U.S., 285 SCIENCE 384 (1999).

10. The failure of the WTO Conference at Seattle was celebrated as a victory of grass-roots democracy over the undemocratic rule of the WTO and the multinational corporations. See, e.g., Vandana Shiva, This Round to the Citizens, The Guardian, Dec. 8, 1999, available at http:// www.guardian.co.uk/print/ 0,3858,3939018,00.html; Barry Coates, Friends Fall Out, THE GuaRDinN, Dec. 8, 1999, available at http:// www.guardian.co.uk/print/0,3858,3939015,00.html.

11. See Globalising Poverty, supra note 9, at 6-7 (reviewing various recent critiques of the Bretton Woods system).

12. See Andrew Marr, The Seattle Debacle Has Raised Crucial Questions About the Role of the World Trade Organisation, The Observer, Dec. 5, 1999, at 28.

13. Friends-of-the-Earth, Fools' Gold-The General agreement on Tariffs and Trade and the Threat of Unsustainable Development 5 (1992) (criticizing the new dispute settlement mechanism of the WTO, which was set by the "Understanding on Rules and Procedures Governing the Settlement of Disputes," Annex 2 to the WTO Agreement); see also Third World Network, Statement from Members of International Civil Society Opposing a Millennium Round or a New Round of Comprehensive Trade Negotiations, at http://www.twnside.org.sg/title/wtomrcn.htm (last updated Aug. 4, 1999) (the Statement was signed by several hundred NGOs before the 1999 WTO third ministerial conference); A Ten-Point Plan to Fight for the Americas: No to FTAA, at http://www.citizen.org/trade/ftaa/articles.cfm? id =8483 (last visited Feb. 27, 2003) (criticizing the proposed Free Trade Area of the Americas (FTAA) in a similar fashion for "setting up dispute resolution processes which refer disagreements to secret international trade tribunals above and outside of national judiciaries which allow foreign governments and corporations to bypass a nation's courts and legal system"). 
remains a difficult task. Two questions seem to lie at the heart of this difficulty. First, what does the notion of "legitimacy" mean in the transnational context? Second, in what sense does the call for "democratization" solve the problem of "legitimacy"? These difficulties point to the deep problem of the association between legitimacy and democracy at the transnational level.

This article seeks to confront this problem by taking a closer look into this coupling. In its first part (sections I to III) the article reviews some of the more prominent responses to the challenge of transnational legitimacy: from the Westphalian-inspired concept of "indirect democratic supervision," to the more universalistic ideas of "NGOs-led democratization" and "directly deliberative democracy." This article argues that none of these narratives provides a convincing response to the democracy/legitimacy puzzle. In its second part (sections IV and $\mathrm{V}$ ), the article develops an alternative interpretation to the problem of legitimacy (and its resolution), drawing on the ideas of "normative creativity" and "social pluralism."

Before proceeding with the argument, it is important to take a closer look at the idea of "legitimate law" (or "authority"). ${ }^{14}$ One possible approach to this concept views the question of legitimacy from a functional or substantial perspective: to the extent that a transnational norm promotes the common good, it should be seen as legitimate. From this perspective, the process leading to the adoption of a certain norm is not relevant to the question of its legitimacy. Under this account, democracy has no role in the creation of legitimacy: the question is rather which set of criteria constitutes the best expression of the common good. There are numerous answers to this question-from economics to science and religion-each with its own community of experts. The declining trust in experts and professional expertise, however, has eroded significantly the power of

14. See Robert O. Keohane \& Joseph S. Nye, Jr., Between Centralization and Fragmentation: The Club Model of Multilateral Cooperation and Problems of Democratic Legitimacy, John F. Kennedy School of Government, Harvard University, Working Paper No. RWP01-004, 2001 (showing that the notion of legitimacy has been subject to various interpretations); see also Daniel M. Bodansky, The Legitimacy of International Governance: A Coming Challenge for International Environmental Law?, 93 AM. J. INr'L L. 596, 596-624 (1999) (arguing that legitimacy "concerns the justification of authority; it provides grounds for deferring to another's decision, even in the absence of coercion or rational persuasion" and that theories of legitimacy "attempt to specify what factors might serve as justifications."); J.H.H. Weiler, Does Europe Need a Constitution? Reflections on Demos, Telos, and Ethos in the German Maastricht Decision, in The Question of Europe 265, 265-94 (Peter Gowan \& Perry Anderson eds., 1997). 
expert knowledge to provide privileged accounts of the common good and, hence, to serve as a source and arbiter of legitimacy. ${ }^{15}$

The broadening acceptance of the democratic ideal in contemporary (global) society means that the legitimacy of transnational regimes is judged, increasingly, by the nature of the process that led to the regimes' creation, and by the public accountability of those who implement them. ${ }^{16}$ This tendency reflects a widely-shared expectation that the people affected by a certain normative structure should be involved in its design and implementation. Legitimacy is seen as a measure of consent and control. The continuing protests against "globalization," then, seem to be motivated by a feeling that the current political map does not provide an adequate response to this widely-shared expectation. This political failure is twofold. On one hand, despite all the talk about globalization, we still lack the necessary institutional mechanisms that could enable a worldwide democratic experience. There is no global political center from which the legitimacy of transnational norms (and the systems that produce them) could be derived. On the other hand, the institutions of the "nation-state" - which still operates as the main locus for political action-offer no real solution to this global deficiency (in contrast to what is postulated by the Westphalian paradigm). ${ }^{17}$

The increasing dissatisfaction with the traditional mechanisms of legitimization (from professional expertise to the institutions of the nation-state) points, then, to the importance of developing alternative accounts of legitimacy. This challenge is taken here. The article is organized as follows. Part I examines in more detail the structure of one of the new domains of transnational law - that of technical standardization. It looks, in particular, into the role of one key player: the ISO. This short case study explores two questions that underlie the broader

15. See Brian Wynne, May The Sheep Safely Graze? A Reflexive View of the Expert Lay Knowledge Divide, in Risk, Environment and Modernity 44 (Scott Lash et al. eds., 1996) (showing the fate of the atomic and bio-science industries as a recent example of this phenomenon and discussing the decline of the "expert-rule").

16. The decline of "expertism" has not been absolute. There are still many occasions on which the legitimacy of legal regimes is judged, mainly according to particular substantial criteria, as expressed in the opinions of the relevant expert community. The case of the Climate Change Convention and the Intergovernmental Panel on Climate Change is a good example. See infra notes $51-58$.

17. For more extensive critique of the Westphalian paradigm, see Teubner, supra note 1, at 3-30; see also Paul Wapner, Politics Beyond the State: Environmental Activism and World Civic Politics, 47 WORLd Pol. 311 (1995); Eyal Benvenisti, Exit and Voice in the Age of Globalization, 98 Mıch. L. Rev. 167 (1999); infra Part II. 
concerns of this article. First, to what extent does this new normative domain raise issues of public concern? How critical is the encroachment of the ISO into the civic domain? Second, to what extent does the decisionmaking structure of the ISO provide opportunities for public participation? Part II provides a more detailed critique of the Westphalian narrative and its legitimization argument (the notion of "indirect democratic supervision") and argues that this narrative fails to provide an adequate response to the challenge of legitimacy.

Part III considers the more universalistic approaches of "NGO-led democratization" and "directly deliberative democracy". While these two responses offer a challenge to the state-centered logic of the Westphalian model, both remain unconvincing in their attempt to resolve the legitimacy/democracy puzzle. Part IV looks more closely at the theoretical underpinnings of the idea of "directly deliberative democracy". It argues that none of the possible pathways that lead from democracy - in its directly deliberative interpretation-to legitimacy are convincing. The fragility of the legitimacy/democracy connection points, then, to the need for an alternative understanding of legitimacy, for another standpoint from which to observe the current calls for the democratization of transnational law. The section concludes by putting forward such an alternative viewpoint, drawing on the idea of "creative norm-making" or "creative institution."

\section{An Illustrative Study: The Case of the International Organization for Standardization}

This section examines the story of a particular system of transnational law: the field of technical standardization. The International Organization for Standardization (ISO), together with the International Electrotechnical Commission and the Codex Alimentarius Commission, play a major role in the process of norm production in this field. This section takes a closer look at the ISO. The discussion in this section is guided by two key questions. First, to what extent has the ISO encroached onto the civic domain, and should the public care about the work of the ISO? Second, does the public have any say in the standard-setting process within the ISO?

The ISO, unlike, for example, the World Trade Organization (WTO), is predominantly a private body. It is a worldwide federation of national standardization 
bodies from some 140 countries (one from each country). ${ }^{18}$ The work of the ISO covers all technical fields except electronic engineering and telecommunication. ${ }^{19}$ The establishment of the WTO in 1995 transformed the normative status of ISO standards. The drafters of the WTO sought to confront the trade barriers caused by the existence of multiple technical and sanitary standards across the globe by giving a boost to the process of standards harmonization. The main vehicles for this effort were the Agreement on the Application of Sanitary and Phytosanitary Measures (SPS Agreement) and the Agreement on Technical Barriers to Trade (TBT Agreement). ${ }^{20}$ The adoption of these two agreements has enhanced significantly the normative authority of international standards-including those of the ISO. ${ }^{21}$

18. These national standard-setting bodies differ quite extensively in their institutional structures. Some are governmental agencies (e.g., the French representative, AFNOR), while others are strictly private (e.g., the British Standards Institution). The ISO should therefore be classified more accurately as a hybrid body, in which private and governmental interests intermingle.

19. For the international standard-setting body covering these two fields, see the International Electrotechnical Commission and the International Telecommunication Union Website, at http:/ /www.itu.int/ itu-t (last visited Feb. 26, 2003).

20. The SPS Agreement deals primarily with measures to protect human, animal or plant health from hazards associated with agricultural products. See Agreement on the Application of Sanitary and Phytosanitary Measures, http://www.wto.org/english/tratop_e/sps_e/spsagr_e.htm [hereinafter SPS Agreement]. Regulations that cover other types of products are covered by the TBT Agreement. See Agreement on Technical Barriers to Trade, http://www.wto.org/english/ docs_e/legal_e/17-tbt_e.htm [hereinafter TBT Agreement]. These agreements also allow the WTO legal system to interfere in an unprecedented way in the regulatory choices of WTO Members (covering also the scientific justification of their regulatory regime). Reinhard Quick \& Andreas Bluthner, Has the Appellate Body Erred? An Appraisal and Criticism of the Ruling in the WTO Hormones Case, 2 J. INT'L Econ. L. 603, 627 (1999).

21. This endorsement or empowerment was achieved through several provisions in the $S P S$ and TBT Agreements. First, both the TBT and SPS Agreements call upon WTO Members to base their domestic regulations on international standards when they exist, and to take part in their preparation. SPS Agreement, supra note 20, arts. 3.1, 3.4; TBT Agreement, supra note 20, arts. 2.4, 2.5. These broad, non-obligatory provisions are supported by another set of provisions that create a presumption in favor of measures that conform to international standards, guidelines and recommendations. Such measures or standards shall be considered as consistent with the provisions of the TBT and SPS Agreements and the GATT 1994. SPS Agreement, supra note 20, art. 3.2; TBT Agreement, supra note 20, art. 2.5. This presumption provides an important incentive for states to adopt the international standards. The SPS Agreement refers in this context to three standard-setting bodies: the Codex Commission, the International Office of Epizootics, and the organizations that operate within the framework of the International Plant Protection Convention. SPS Agreement, supra note 20, art. 3.4. The TBT Agreement does not contain a reference to a particular organization. It includes, instead, a general definition of an "international body." See TBT Agreement, supra note 20, Annex 1, art. 4. The major international players in this context are the ISO and the International Electrotechnical Commission. 
Despite its seemingly technical character, the work of the ISO has far-reaching social implications that are not limited to the corporate domain. Perhaps the best example of the societal importance of the ISO normative work may be found in its new set of environmental standards, the ISO 14000 series. The ISO 14000 series includes standards for environmental management systems, environmental auditing, environmental performance evaluation, environmental labeling, and life cycle assessment. ${ }^{22}$ The ISO 14001 standard is the most widely used standard for environmental management systems. ${ }^{23}$ Unlike some of the ISO's other products, the ISO 14000 series is not really "technical"- -at least not in the usual sense of this term. It does not deal with technological questions ${ }^{24}$ or with emissions standards.

Rather, the ISO 14000 series reflects an attempt to forge a complete (pragmatic) philosophical manual for organizations. This manual does not offer detailed technological or emissions protocols, but seeks to teach organizations, in a general and abstract fashion, how to think about environmental problems. Furthermore, the normative aspiration of the ISO 14000 series is not limited to the corporate realm. It seeks to provide a comprehensive normative discourse that will be used by society as a whole for judging the environmental behavior of organizations. This ambitious agenda is embedded in a particular environmental philosophy, which views environmental dilemmas as primarily technical

22. See ISO 14000 Website, at http:/www.iso.ch/iso/en/iso $9000-14000 /$ isol $4000 /$ isol 4000 index.html; see also Murray, supra note 9, at 35-71.

23. Int'l Org. for Standardization, ISO i 4 oor: Environmental Management SystemsSpecifications with Guidance for Use (1996) [hereinafter ISO 14001]. A second standard, the ISO 14004, includes a guidance manual. ISO 14004: Environmental Management SystemsGeneral Guidelines on Principles, Systems and Supporting Techniques (1996); see also ISO 14001 and EMAS Sites World-Wide, 5 J. Inst. Envtr. Mgmt. 3, 6(1998) (survey showing that there were 5,637 ISO sites against 2,141 sites for the competing European standard-the European Eco-Management and Audit Scheme (EMAS)-in September 1998). In recognition of the increasing popularity of the ISO 14001 Environmental Management System, the new version of the European Eco-Management and Audit Scheme (EMAS) incorporates it as its environmental management system. See EMAS Website, at http://europa.eu.int/comm/ environmentemas/ index_en.htm.

24. Pollution control equipment could be based on a variety of different technologies. In the context of air pollution these might include scrubbers, which use water to remove SOx and particulates from exhaust gases; incinerators (or thermal oxidizers), which use intense heat to destroy organic contaminants; baghouses, which trap and remove particulates from an exhaust stream; and catalysts, which cause chemical reactions that break the pollutants down into less harmful byproducts. 
problems of management and engineering. This technocratic stance leaves unchallenged the basic narratives of economic growth and appropriation of nature that guide the contemporary corporate world. The vision of the ISO 14000 series is, therefore, highly anthropocentric: nature is posited as a mute resource with no independent political or moral standing. With its ambitious normative reach, and its controversial philosophical outlook, the ISO 14000 initiative should have been the subject of a wide-ranging deliberation process. This process, however, never took place. The principles on which the ISO 14000 is based, to which I will return below, reflect this lack of public deliberation.

Consider first the structure of the standard-making process in the ISO. A thorough discussion of the ISO "constitutional" framework is beyond the scope of this article. A brief exposition will suffice to demonstrate the shortcomings of this framework. ${ }^{25}$ The standard-setting process within the ISO provides little (if any) opportunities for public participation. According to the organization's by-laws, only ISO members have the right to receive drafts, make comments, and approve ISO standards. ${ }^{26} \mathrm{Non}$-governmental organizations can only gain access to the ISO standard-setting process as "liaison" organizations, a status that enables them to

25. See U.N. Conference on Trade and Development, ISO iquot: International Environmental Management Systems Standards: Five Key Questions for Developing Country Officials 21-40 (1996) [hereinafter Five Key Questions]. The closed structure of the ISO lawmaking process can be contrasted with the Global Reporting Initiative (GRI)-which, through a much more open and inclusive process, seeks to develop standards of sustainability reporting. GRI Website, at http:// www.globalreporting.org.

26. For a description of the standard setting process, see ISO, ISO/IEC Directives, Part I: Procedures for the Technical Work 19-30 (4th ed. 2001) [hereinafter ISO/IEC Directive]; see also ISO, Stages of THE Development of International Standards, $a t \mathrm{http} / / \mathrm{w} w \mathrm{w}$.iso.ch/iso/en/stdsdevelopment whowhenhow/proc/proc.html. The ISO constitution distinguishes between 3 forms of membership. Full members have the right to participate as P-members in Technical Committees, which gives them the right and obligation to vote on all questions submitted for voting within the technical committee, including enquiry drafts and Final Draft International Standards. Correspondent Members can only participate in the standard-setting work as Observing Members (O-Members), which allows them to attend meetings, receive documents and submit comments. A third category-subscriber membership-establishes only a very limited contact with the ISO, and is usually reserved for countries with very small economies. See ISO, INTropuction: ISO MeMBERS, at http://www.iso.ch/ iso/en/aboutiso/isomembers/index.html; see also ISO/IEC Directive, supra, II 1.7.1. The ISO is currently introducing a sophisticated system for electronic balloting, which will become operative during 2001 and 2002. While the system should improve substantially the internal democracy of the ISO, it will do very little to make the institution open to the voices of non-members. See Reinhard Weissinger, Electronic Balloting: Get Ready-Vote Electronically!, 32 ISO BULLETIN 3 (2001). 
observe the standard-setting process but not exercise formal voting rights. Furthermore, to gain this limited access, NGOs have to get the approval of the ISO Chief Executive Officer. ${ }^{27}$ The closed nature of the norm-production process in the ISO is reflected also in the highly non-transparent character of the organization. The ISO does not offer free access to approved standards or to draft versions of future standards. External observers must purchase the standards if they want to review them. ${ }^{28}$

A 1996 UNCTAD Report, which examined the participatory profile of the work that led to the publication of the ISO 14000 series, sheds some light on the problematic nature of this constitutional set-up. ${ }^{29}$ The preparatory work for the ISO 14000 was coordinated by a special Technical Committee (TC 207). The UNCTAD report examined the share of developing countries in the work of TC 207. While sixty-eight percent of ISO full members are developing countries and only twenty percent are developed countries, developing countries constituted only forty-nine percent of TC 207 membership (against a forty-three percent share of developed countries). ${ }^{30}$ Furthermore, despite their seemingly "equal" share in the formal membership of TC 207, developing countries had a much lower share in the actual work of the committee. ${ }^{31}$ The UNCTAD Report further indicates that there was almost no civic participation in the preparation of the ISO 14000 standards. ${ }^{32}$

The principles on which the ISO 14000 is based reflect the closed nature of the organization. The ISO 14001 standard seeks to create a framework that will encourage organizations to improve continuously their overall environmental

27. See ISO/IEC DiRECTIVE, supra note 26, \$1 1.17.3.

28. The ISO retains intellectual property rights over all of its standards. Indeed, $20 \%$ of its budget is based on revenues from the sale of the Organization's standards and other publications. See Int'l Org. of Standardization, Introduction: How is ISO's Work Financed?, at http:/ www.iso.ch/iso/en/aboutiso/ introduction/finance.html.

29. See Five Key Questions, supra note 25.

30. Id. at 25. The rest were countries from Central/Eastern Europe.

31. This conclusion draws on an analysis of two important meetings of TC 207, which took place in Oslo and Rio in 1995 and 1996. The Report notes that a survey of the participants indicates that only a small share of the developing-country members had actually participated in the meetings. This was reflected also in the substantial difference in the size of the delegations. Thus, for example, in Oslo 79\% of the delegates were from developed countries and in Rio, 55\%. The Oslo meeting was particularly important because this was where approval of the ISO 14001 standard as a Draft International Standard was discussed. See id. at 23-26.

32. See id. at $22-23$. 
performance. ${ }^{33}$ It attempts to achieve this goal through a very simple scheme, based on five general principles: commitment and policy, planning, implementation, measurement and evaluation, and, finally, review and further implementation. What links these principles together is a general commitment to a dynamic cyclical process of "plan, implement, check and review." 34

This conceptual framework is highly problematic. In the first place, it gives the organization wide discretion, both in devising its environmental plan and in designing the environmental indicators according to which it will measure its performance. ${ }^{35}$ If the basic compliance level derived from the local regulatory framework is low, as might be the case in many developing countries, the commitment for "continual improvement" might mean very little. ${ }^{36}$ A second weakness of the ISO 14001 model concerns its approach to the issue of public participation. Article 4.4.3 of ISO 14001 requires the organization only to "consider processes for external communication on its significant environmental aspects and [to] record its decision." ${ }^{37}$ The organization is not required to publish an annual environmental statement. ${ }^{38}$ The non-participatory nature of the ISO is reflected then in the structure of the standards themselves. The ISO constitutes a paradigmatic example of democratic deficiency in the new global legal arena.

33. See ISO 14001 , supra note 23 , at 6 .

34. Id.; see also Murray, supra note 9, at 45-48.

35. The introduction to ISO 14001 provides that: "[T|his International Standard does not establish absolute requirements for environmental performance beyond commitment, in the policy, to compliance with applicable legislation and regulations and to continual improvement." ISO 14001 , supra note 23 , at 6 .

36. Note also that under the ISO 14001 scheme, a firm can legitimately respond to nonconformance by reducing the stringency of its declared goals on the ground that the initial goals were "inappropriate" (as long as the new goals comply with the local law). See Jason Switzer \& John Ehrenfeld, Independent Environmental Auditors: What Does ISO 14001 Registration Really Mean?, Envtr. Quality Mgmt., Autumn 1999, at 27.

37. ISO 14001, supra note 23, art. 4.4 .3 (emphasis added).

38. Switzer \& Ehrenfeld, supra note 36 , at 29 . This approach to the disclosure issue mainly reflects the concern of the U.S. business community that such disclosure would act as a platform for criminal or civil litigation, and not as a basis for constructive dialogue. Id. at 27; see also Murray, supra note 9, at 53-54. The U.S. business community has been pushing for the adoption of statutory mechanisms that would provide those organizations that have a certified EMS program with some immunity from liability, or a qualified privilege. This campaign has succeeded in prompting some legal changes. Murray, supra note 9, at 53-62. 


\section{The Fallacy of Westphalia}

Despite continuous and various critiques, the Westphalian vision still plays a major role in the debate about the legitimacy of transnational legal structures. Those who adopt the Westphalian viewpoint are willing to admit that over the last decade, there has been a significant shift in the balance of power between the state and transnational levels. They maintain, however, that this transfer of power does not require any radical changes in the way global governance is produced, and, in particular, should not change our basic conception of the nationstate as the main arena for political deliberation (and the ultimate source for legitimacy). I will argue that the Westphalian argument is unconvincing. To appreciate this claim we need to examine more closely the structure of the Westphalian argument.

From the Westphalian perspective, international law was understood as a product of diplomatic negotiations between sovereign states. ${ }^{39}$ As such, its "legitimacy" was derived solely from state consent ${ }^{40}$ - whether to a specific set of norms, or to the establishment of an international body with norm-producing powers. The state citizenry played no role in the production of consent or, indeed, legitimacy. The Westphalian version of international law cared very little about the nature of the domestic political process that preceded the formal act of consent. ${ }^{41}$ The consent requirement was interpreted as a purely formalistic con-

39. Thus, for example, international environmental law was defined as the "collective body of agreements among states regarding mutual rights and obligations affecting the environment. . . Enforcement of its provisions, customary or specified by treaty, are usually sought through negotiation (e.g., diplomacy) rather than through adjudication." See Lynton K. Caldwell, International Environmental Policy: From the Twentieth to the Twenty-First Century 146 (3rd. ed. 1996) (emphasis added).

40. The strongest expression of this view is the Vienna Convention on the Law of Treaties, May 23, 1969, 1155 U.N.T.S. 331 [hereinafter Vienna Convention] (explaining in particular the definitions of "ratification," "acceptance," "approval," and "accession" in Article 2 of the Convention); see also Bodansky, supra note 14, at 604.

41. Thus, the only hint in the Vienna Convention to the possible tension between the formal consent of the state and the will of the people is indirect. Article 46 provides that: "(1) A State may not invoke the fact that its consent to be bound by a treaty has been expressed in violation of a provision of its internal law regarding competence to conclude treaties as invalidating its consent $u n$ less that violation was manifest and concemed a rule of its internal law of fundamental importance; (2) A violation is manifest if it would be objectively evident to any State conducting itself in the matter in accordance with normal practice and in good faith." Vienna Convention, supra note 40, at art. 46 (emphasis added). 
dition. ${ }^{42}$ Contemporary writers have tried to add a democratic twist to this very formalistic story. The consent requirement was interpreted not just as a formal rule of constitutional adequacy, but as a reflection of more substantial demand: to subject the diplomatic process, which took place at the transnational level, to a meaningful bottom-up political supervision. While the structure and spirit of this supervision were to be determined by the state and not by international law, it was assumed, nonetheless, that the consent of the state was a product of meaningful political deliberation. ${ }^{43}$

The social transformations of the last decade, however, have cast deep doubts on this narrative of legitimacy. ${ }^{44}$ First, the vision of indirect democratic supervision is based on an unrealistic view of the political game within the state. Contrary to the assumptions of the Westphalian model, the constitutional framework of most states does not provide a suitable space for discussing transnational issues, nor does it create proper mechanisms for monitoring the processes (e.g., international negotiations, inner-institutional deliberations) that lead to the creation of transnational norms. Second, and more importantly, the Westphalian vision of a highly fragmented political plane, comprised of detached polities, is at odds with the intensifying societal demand to subject transnational normative processes to worldwide deliberation. Global dilemmas cannot be debated in a fragmented fashion; they require a global conversation. The Westphalian model of fragmented deliberation and detached polities is seen, then, as a barrier to the development of more internationally oriented communicative processes.

A further difficulty with the Westphalian worldview stems from its very strict interpretation of "delegated authority." This interpretation provided the rationale and justification for the creation of international institutions with normmaking powers. Under this understanding, the various international institutions set up through treaty-making processes were portrayed as highly controllable entities that were completely dependent on the states that had put them in place. This portrait fails to appreciate, however, the increasingly autonomous nature of

42. Id. art. 7.

43. See, e.g., Ernst-Ulrich Petersmann, Dispute Settlement in International Economic Law: Lessons for Strengthening International Dispute Settlement in Non-Economic Areas, 2 J. INT'L EcoN. L. 189, 231 (1999).

44. See Robert Howse, Adjudicative Legitimacy and Treaty Interpretation in International Trade Law: The Early Years of WTO Jurisprudence, in THE EU, THE WTO, AND THE NAFTA: TOWARDS A Common Law of International Trade?, 35 (J.H.H. Weiler ed., 2001). 
these global legal networks, and the fact that they rely on bases of support located outside that state system. In that sense, these transnational legal systems are shielded, in varying degrees, from the influence of inter-state politics. This kind of deep independence characterizes both state-oriented regimes such as the $\mathrm{WTO}^{45}$ and global private regimes, such as standardization or internet domains.

Consider, in this context, two examples of state-oriented systems: the World Trade Organization and the Climate Change Convention. ${ }^{46}$ While the WTO is indeed a product of multilateral negotiations between nation-states, its legal system is highly autonomous. Neither the political forum of the WTO (that is the WTO membership acting as a collective) nor the WTO Secretariat (the executive branch of the WTO) has the right to interfere directly in the operation of the WTO adjudicative system. ${ }^{47}$ WTO members are obliged to fulfill the results of the adjudication process, and may suffer sanctions if they fail to do so. ${ }^{48}$ Therefore, the WTO legal tribunals- the panels and the Appellate Body-enjoy a substantial degree of autonomy in their judicial work. While a WTO member can, of course, withdraw its membership from the $\mathrm{WTO},{ }^{49}$ this course of action is very problematic, because most members-even superpowers like the United States and the European Union-are highly dependent on the legal framework that was created by the WTO treaties. Furthermore, the WTO does not rely only on the

45. For a survey of some of these other systems, see Petersmann, supra note 43, at 208-29. Paradoxically, the much older International Court of Justice has turned into a minor player in the international legal arena because of its limited jurisdiction.

46. United Nations Framework Convention on Climate Change, May 9, 1992, U.N. Doc. A/ CONF.151/26, reprinted in 31 I.L.M. 849.

47. To be more precise, the WTO political forum (acting in its capacity as the Dispute Settlement Body) can overrule the decisions of the WTO judicial bodies only by full consensus. Since the winning party is unlikely to join such a political maneuver it seems highly improbable that such a consensus could be attained in practice. The autonomy of the WTO legal system is guaranteed by the Understanding on Rules and Procedures Governing the Settlement of Disputes, Dec. 15, 1993, 33 I.L.M. 112 [hereinafter DSU]. The "reverse" consensus principle is elaborated in Articles 16.4 and 17.14 of the DSU. The Dispute Settlement Body was created to oversee the operation of the DSU. Id. art. 2. Its composition is identical to that of the WTO General Council. Id. art. 4.3. In this context, the WTO differs, substantially, from its predecessor, the GATT. For a more detailed discussion of the WTO legal system, see Oren Perez, Ecological Sensitivity and Global Legal Pluralism: Rethinking the Trade and Environment Debate (2001) (unpublished Ph.D. dissertation, London School of Economics and Political Science) (available at the London School of Economics library).

48. DSU, supra note 47 , arts. $22,23$.

49. This is unlike most citizens, who cannot leave their country (in a practical sense) if they do not agree with the rulings of their national legal system. 
support of the state system. The expanding community of multinational enterprises, which is highly dependent on the pro-trade climate that the WTO facilitates, constitutes an important source of non-state support for the WTO. ${ }^{50}$

Similarly, the normative aspirations of the Climate Change Convention do not depend only on political support from the inter-state level. They also reflect (a-political) scientific and moral conversations that take place at the global level. ${ }^{51}$ A good example is the work of the Intergovernmental Panel on Climate Change (IPCC). The IPCC plays a key role in the assessment of the scientific, technical, and socio-economic information relevant for the understanding of the risk of human-induced climate change. ${ }^{52}$ Its various reports provide independent support for the normative aspirations of the Climate Change Convention and the Kyoto Protocol. Thus, for example, in its 2001 Report, the IPCC Working Group I reconfirmed that "[e]missions of greenhouse gases and aerosols due to human activities continue to alter the atmosphere in ways that are expected to affect the climate." ${ }^{53}$ The Report argued that these activities are likely to cause a rise in global average temperatures and sea level, which, in turn, are likely to trigger extreme climatic phenomena. ${ }^{54}$ It further noted that improvement in modeling techniques enables scientists to be more confident in their ability to make useful projections of future climate. ${ }^{55}$ So, when George W. Bush decided to renege on the semi-formal obligations of the United States under the Kyoto

50. With the increase-in scale and scope-of transnational commerce, the level of this political backing outweighs the opposition of local, non-exporting, industries.

51. For the role of scientific communities in shaping environmental regimes, see, e.g., Peter $M$ Haas, Banning Chlorofluorocarbons: Epistemic Community Efforts to Protect Stratospheric Ozone, 46 INT'L ORG. 187, 187-88 (1992). The remaining influence of such communities stands in contrast to the visible decline in the trust in experts. It is hard to reconcile these two phenomena.

52. See IPCC Website, at http://www.ipcc.ch. IPCC was èstablished in 1988 by the World Meteorological Organization and the United Nations Environment Programme. It groups together dozens of scientists from all over the world, basing its assessment mainly on published literature (it does not carry out new research).

53. Climate Change 200 i: The Scientific Basis 5 (J.T. Houghton et al. eds., 2001) [hereinafter Scientific Basis]. Current data indicates that the atmospheric concentration of $\mathrm{CO}_{2}$ has increased by $31 \%$ since 1750 . The carbon cycle models, which were surveyed by the IPCC, found that by $2100, \mathrm{CO}_{2}$ concentrations are likely to increase by 90 to $250 \%$. Id. at 7,12 .

54. Id. at 13, 15. These extreme phenomena include, for example, more intense precipitation events in the Northern Hemisphere's mid to high latitude land areas, and increased summer continental drying and associated risk of drought. Id. at 15 .

55. Id. at 9 . 
Protocol, ${ }^{56}$ he had to consider not only the potential reactions of its governmental counterparts, but also how its decision might be seen in light of these independent global discourses. In justifying his opposition to the Kyoto Protocol in terms of the "incomplete state of scientific knowledge of the causes of, and solutions to, global climate change," ${ }^{57}$ President Bush risks losing his political credibility because of the inconsistency of his arguments with the findings and conclusions of the recent IPCC report. ${ }^{58}$

The final blow to the Westphalian worldview and its notion of "indirect democratic supervision" comes from the increasingly important role of private international regimes in today's world. When we move to the private domain-to the realm of the lex mercatoria or to the domain of technical standardization-the Westphalian idea of state consent loses any credible meaning. The traditional doctrine of international law viewed the legitimacy of these legal structures through the lexicon of "private international law." In the eyes of private international law, these "private global regimes" derived their power and legitimacy either from the autonomous will of individuals (or firms) who freely adopt them in voluntary market transactions (the freedom of contract hypothesis), or from the decision of the state formally to endorse them (the endorsement hypothesis).

Both of these hypotheses fail to characterize properly the way in which these new forms of private law are communicated and employed in practice. This failure stems primarily from a disregard of the constraints that face individuals,

56. Julian Borger, Bush Kills Global Warming Treaty, The GuARdian, Mar. 29, 2001, available at http://www.guardian.co.uk/globalwarming/story/0,7369,464920,00.html.

57. Letter from George Bush, President of the United States, to Senators Hagel, Helms, Craig, and Roberts, Members of United States Congress (Mar. 13, 2001), htrp://www.globalclimate.org/ bushletter.htm.

58. The last report of the IPCC was used extensively by the media in this context. See, e.g., Tim Radford, Top Scientists Isolate Bush by Backing Kyoto, The Guardian, May 18, 2001, available at http://www.guardian.co.uk/globalwarming/story/0,7369,492776,00.html; see also William K. Reilly, A Climate Policy That Works, N.Y. Times, Apr. 1, 2001, sec. 4 at 17; Global Flip-Flop, Boston GLoвe, Mar. 30, 2001. The IPCC scientists draw completely different conclusions from their data. They argue that "[r]eductions in greenhouse gas emissions and the gases that control their concentrations would be necessary to stabilise radiative forcing." In practical terms this would require "global anthropogenic $\mathrm{CO}_{2}$ emissions to drop below 1990 levels, within a few decades ... and continue to decrease steadily thereafter. Eventually $\mathrm{CO}_{2}$ emissions would need to decline to a very small fraction of current emissions." ScIEnTific Basis, supra note 53, at 12 (emphasis added). The Bush administration has recently asked the National Academy of Science (NAS) to assess the conclusions of the IPCC 2001 Report. The NAS Report generally confirms the IPCC conclusions. See NaS Committee on the Science of Climate Change, Climate Change Science: An Analysis of Some Key Questions (2001). 
firms, and states when they decide whether to accept a particular (private) norm. In the first place, many of these new legal systems, and their associated lawmaking institutions, enjoy substantive market power (or, rather, normative power). ${ }^{59}$ The freedom of contract metaphor ignores this normative power, and thus does not give a realistic account of the spectrum of choices that individuals or firms face when they decide whether to adopt a particular norm. The endorsement hypothesis suffers from similar flaws. First, much like individuals, nations are influenced by market power considerations. Thus, for example, in its recent environmental management regulation, the European Commission has decided to adopt the ISO 14001 standard as its environmental management system because it found that the system established by the original regulation could not compete successfully against the ISO standard. ${ }^{60}$

Second, the capacity of nation-states to interfere in these norm-production processes, whether directly or through non-endorsement, has been substantially eroded by a variety of multilateral treaties, the most important of which is the 1958 New York Convention on the Recognition and Enforcement of Foreign Arbitral Awards. The New York Convention ensures a worldwide exclusive jurisdiction to arbitration proceedings based on valid arbitration agreements, provides procedures for the recognition and enforcement of foreign awards, and limits the grounds on which domestic courts can refuse requests for enforcement to a few basic procedural defects. The adoption of the principle of non-interference has turned the New York Convention into more than a mechanism of enforcement; it created a space of non-interference in which these different systems of global law could have evolved independently of the influence of inter-state politics. ${ }^{61}$ While the new transnational legal regimes do build on the legal infrastructure of the nation-state (e.g., for enforcement services), they developed various mechanisms that shelter them from extensive state-sponsored intervention.

The contemporary institutions of the nation-state fail, therefore, to provide a suitable answer to the democratic challenge of the new "law without a state." 62

59. The new WTO regime has contributed to this market power, especially in the context of standardization processes, through the SPS Agreement and the TBT Agreement. See SPS Agreement, supra note 20; TBT Agreement, supra note 20.

60. See Environmental Management System Requirements, Annex I of the revised EMAS, http:// www.europa.eu.int/comm/environment/emas.

61. As of March 20,2003, the Convention had 133 parties. Updated data about the status of the Convention can be found at the UNCITRAL Website, at http://www.uncitral.org/en-index.htm (last visited Apr. 26, 2003).

62. The phrase was coined by Gunther Teubner. See generally Teubner, supra note 1. 
The capacity of the state to act as an exclusive source and arbiter of legitimacy has been substantially eroded.

\section{The Universalistic Dream: \\ From NGO-Led Democratization to Direct Deliberation}

The ideas of NGO-led democratization and direct deliberation have grown out of a deep dissatisfaction with the Westphalian-inspired separation between the state and inter-state levels. They reflect an attempt to substitute the fragmented vision of the Westphalian paradigm with a more universalistic vision of democracy seeking to redefine the space in which governance is produced. While these two narratives share a common vision-the need to develop a worldwide democratic experience-they differ in the way in which they envision this experience, and the conditions for its realization. This section provides both an introduction and critique of these two models.

Before I proceed to a critique of these two models, I want to put aside a more radical vision of transnational democracy: global federalism. The thesis of global federalism is that a global federal framework might be developed on the U.S. or EU model, with an independent parliament, executive branch, and a unified legal system (with unlimited jurisdiction and an enforcement mechanism) ${ }^{63}$ Despite its various appeals, I do not believe this thesis provides a plausible starting point for the project of transnational democracy. First, its inconsistency with the traditional concept of state sovereignty does not seem to take into account the strong staying power of the nation-state. Second, it is not clear that such an ambitious project could actually succeed without the support of a (currently missing) global demos. ${ }^{64}$ Finally, the dangers of erecting such a mammoth bureaucratic structure are substantial. Indeed, the widespread objections within the European Union to the work of the European Commission illustrate the problems that such a mammoth bureaucracy produce: corruption, arrogance, and detachment.

63. See, e.g., David Held, Democracy and the New International Order 18 (1993); David Held, Regulating Globalization? The Reinvention of Politics, 15 INT'L Soc. 394 (2000) [hereinafter Regulating Globalization?].

64. See Bodansky, supra note 14, at 600 . 


\section{A. NGO-Led Transnational Democracy}

The advocates of NGO-led democratization postulate that the NGO community should lead the reform of global politics. Giving NGOs a greater say in the production of transnational norms-by extending their rights of participation in treaty negotiations and international adjudicative processes-should render transnational governance more legitimate. ${ }^{65}$ The incorporation of NGOs in the institutional apparatus that produces transnational norms is put forward, then, as a response to the increasing civic demand for a voice.

This thesis is highly problematic, however, primarily because the logic of legitimacy and democracy that drives it is both incoherent and self-defeating. First, the call for more extensive participation of NGOs leaves unresolved the question of the social legitimacy of these organizations. Most of these organizations are not governed in a democratic fashion. It is not clear why they should be treated as true representatives of the public. ${ }^{66}$ This problem is exacerbated by the fact that NGOs are not truly transnational; they have deep national, geographical, and cultural ties. Those NGOs that have a strong international presence (e.g., Greenpeace, World Wildlife Foundation, and Friends of the Earth) tend to have a strong Northern affiliation. These geocultural ties and biases cast doubts on the ability of the model of NGO-led democratization to bridge the gap between Northern and Southern communities. Indeed, developing countries have been highly suspicious of this idea. Thus, for example, in the recent ShrimpTurtle dispute at the $\mathrm{WTO},{ }^{67}$ all the developing countries that were party to the

65. In the context of the WTO, see Daniel C. Esty, Why the World Trade Organization Needs Environmental NGOs, International Centre for Trade and Sustainable Development Working Paper (1999), available at http://www.law.yale.edw/outside/html/faculty/danesty/wtrade.pdf; see also Steve Charnovitz, Participation of Nongovernmental Organizations in the World Trade Organization, 17 U. PA. J. InT'L Econ. L. 331 (1996); G. Richard Shell, The Trade Stakeholders Model and Participation by Nonstate Parties in the World Trade Organization, 17 U. PA. J. INT'L. ECoN. L. 359 (1996). For a similar argument in the context of the ICJ, see Dinah Shelton, The Participation of Nongovernmental Organizations in International Judicial Proceedings, 88 A M. J. INr'L L. 611 (1994). In many organizations, taking this path would require a radical transformation of their decision-making structure. See id.; see also Shrimp Report, supra note 7.

66. Some NGOs have developed firm cognitive and moral reputations over the last years. These reputations could provide an independent, non-democratic ground for the claim for more extensive participatory rights for NGOs (as a way for improving the substantial quality of governance processes). The proponents of NGO-led democratization, however, tend to ground their claims on democratic, rather than instrumental grounds.

67. Shrimp Report, supra note 7. 
dispute strictly opposed the U.S. proposal to allow NGOs to submit amicus briefs to WTO tribunals. ${ }^{68}$

But this model is not just democratically incoherent. Its implementation could adversely affect civic society itself. Consider, for instance, the case of NGO participation in WTO proceedings. Opening the adjudicative process to NGOs will impose a difficult burden on the WTO legal system. In order to avoid the overcrowding of its adjudicative system, the WTO will have to devise some screening mechanism. This mechanism (however noble the intentions of its designers might be) could have broad "undemocratic" side-effects. First, devising a fair screening criterion is an extremely difficult task. On what basis should the WTO distinguish (and choose) between the manifold environmental, business, art, and labor groups which will knock on its doors? By definition, any screening mechanism will be non-democratic. Furthermore, whatever this criterion might be, it will have to be applied by the WTO itself. The WTO will, therefore, have the power to decide which of these manifold groups is worthy of an entryticket into the trade world ${ }^{69} \mathrm{It}$, will, in other words, act as the supreme coordinator of the NGO world..$^{70}$ But the WTO will not operate just as a gatekeeper. It will function also as a supreme cognitive arbiter. By subjecting themselves to the jurisdiction of the WTO, NGOs will have to accept as legitimate not only the WTO screening authority, but also its cognitive supremacy. This could limit severely their ability to criticize the WTO system from the outside. The WTO (or any other transnational institution) will thus be given the power to intervene in, or even contaminate, the inner world of the global civic society.

68. See id. II 29-33, 46. The meeting of the Dispute Settlement Body (DSB), in the aftermath of the Shrimp decision, reflected a similar mood. See Minutes of Meeting, DSB, Held in the Centre William Rappard, Nov. 6, 1998, WT/DSB/M/50, available through the WTO Documents Gateway: http:// www.wto.org/english/docs_e/docs_e.htm. Surprisingly, none of the delegates of the developed countries (apart from the U.S. delegate) who spoke at the meeting (which included the European Union, Switzerland, Australia and Japan) supported this idea, with Japan strongly objecting to it. The developing countries demonstrate similar suspicion toward the environmental and labor agenda of the developed countries, seeing it as a pretext for protectionism. See, for example, the position of Henrique Cardozo, President of Brazil, in his address at the FTAA meeting in Quebec, quoted in A Cautious Yes to Pan-American Trade, The Economist, Apr. 28, 2001, at 57.

69. One way in which the "screening" problem could be overcome is to give the NGO community the right (and obligation) to decide which organization would have, at any specific dispute, the right to appear before the WTO judicial tribunals.

70. The recent asbestos case, in which the Appellate Body first offered NGOs an opportunity to apply for a leave to submit an amicus brief and then refused all the applications, is a perfect illustration of this problem. See EC-Asbestos, supra note 7, II 50-57. 
The recent experience of the WTO with NGO participation vividly illustrates the problematic of such arrangement. In its recent decision in the Shrimp case, the Appellate Body apparently came a step closer toward accepting the position of its critics, by ruling that WTO panels have the right to accept amicus briefs from NGOs even if the briefs were not explicitly invited by them. ${ }^{11}$ This ruling was seen by some as an important move toward the democratization of the WTO regime. ${ }^{72}$ A closer look at the way in which this ruling was applied in practice, however, reveals a different picture. ${ }^{73}$ First, the Appellate Body made clear that panels have no obligation to accept amicus briefs. ${ }^{74}$ It emphasized that as part of the panels' broad authority over the adjudicative process, any panel has "the discretionary authority either to accept and consider or to reject information and advice submitted to it, whether requested by a panel or not." 75 Second, the way in which the Appellate Body has implemented its liberal interpretation in practice is highly problematic. While the Appellate Body decided to accept the NGO briefs that were attached to the U.S. submissions, it did not consider the substantial arguments that were included in them. ${ }^{76}$ The Appellate Body defended this decision by noting that the "United States has itself accepted the briefs in a tentative and qualified manner only." 77 The Appellate Body thus signaled that in its opinion the submissions of the NGOs were not worthy, in and of themselves, of substantial consideration. This reflects a deep skepticism with respect to the cognitive credibility of NGO representations.

The same kind of ambivalence toward NGOs was demonstrated by the Appellate Body in another more recent case, in the dispute between the European Union and Canada over a French ban on the import of asbestos and asbestos

71. The ruling was based on a liberal interpretation of Article 13 of the Dispute Settlement Understanding, which deals with the right of panels to seek information from third parties. See Shrimp Report, supra note 7, II 99-109.

72. See, e.g., Howse, supra note 44, at 47-51.

73. See Arthur E. Appleton, Shrimp/Turtle: Untangling the Nets, 2 J. InT'L Econ. L. 477 (I999).

74. Shrimp Report, supra note 7, / 104, 108.

75. Id. II 108 (emphasis in original).

76. Id. \89-91.

77. Id. If 91. The Appellate Body notes that the United States "has confirmed its agreement with the legal arguments in the attached submissions of the non-governmental organizations, to the extent that those arguments "concur with the U.S. arguments set out in [its] main submission." Id. II 90. The Appellate Body understood this formulation, quite correctly, as saying the United States is not responsible for contrary views. This, of course, raises the question of the independent credibility of NGOs' submissions. 
products from Canada. ${ }^{78}$ In a controversial move, the Appellate Body decided to enable non-parties to apply for leave to file an amicus brief with the Appellate Body in relation to the dispute. ${ }^{79}$ Several leading environmental groups and research institutions ${ }^{80}$ accepted the Appellate Body's invitation and filed requests to make legal submissions in the case. The Appellate Body decided, however, to refuse all the applications. In its recent decision the Appellate Body noted only that the applicants "failed to comply sufficiently" with the requirements for submission. ${ }^{81}$ It seems somewhat strange that none of the NGOs' briefs submitted to the Appellate Body have complied with its formal requirements.

What facially appeared as a path-breaking jurisprudential innovation had, then, little practical impact on the openness of the WTO legal system. This piece of legal experience is not just a reflection of the WTO organizational culture. It reflects the deep problematic of the idea of NGO-led democratization.

\section{B. Directly Deliberative Democracy and Legitimacy}

The deep shortcomings of the models of global federalism and NGO-led democratization have led many observers and critics to point to directly deliberative democracy as a more tenable vision for transnational democratization. The concept of direct deliberation interprets the democratic process as "collective decision-making that proceeds through direct participation by and reason-

78. WTO Dispute Settlement Decisions, European Communities-Measures Affecting Asbestos and Asbestos-Containing Products, Sept. 18, 2000, WT/DS135. The Panel has rejected the Canadian complaint, accepting the French Article XX(b) argument. The Appellate Body decision, which upheld the Panel ruling, was published on March 12, 2001. See EC-Asbestos, supra note 7.

79. WTO Dispute Settlement Decisions, European Communities-Measures Affecting Asbestos and Asbestos-Containing Products: Appellate Body Communication, Nov. 8, 2000, WT/DS135/9, available at http:// www.wto.org/english/news_e/news00_e/ds135_9.doc, quoted in EC-Asbestos, supra note 7, If 52 (prescribing detailed requirements for the application process in this case).

80. Overall, eleven organizations filed for leave to file a written brief within the time limits set by the Appellate Body, among them Greenpeace International, World Wide Fund for NatureInternational, Ban Asbestos Network, the International Ban Asbestos Secretariat, the Foundation for International Environmental Law and Development (FIELD), and the Center for International Environmental Law (CIEL). EC-Asbestos, supra note 7, II 56.

81. Id. In a special meeting of the WTO General Council on November 22, 2000, the members warned the Appellate Body to proceed with extreme caution in the future with respect to how it deals with NGO participation in the dispute settlement process. International Centre for Trade and Sustainable Development, WTO General Council Slaps Appellate Body on Amicus Briefs, Bridges, Nov. 28, 2000, at 1 . This response, though it has no formal legal meaning, demonstrates how problematic the issue of NGO participation is. 
giving between and among free and equal citizens." ${ }^{2}$ The public in this notion of democracy is interpreted "as the arena in which free and equal citizens reflect on and seek to advance common aims." 83 This democratic vision does not depend for its realization on the development of a comprehensive global polity, with stable, overarching institutions. It offers a more modest vision, which portrays the (transnational) democratic experience as a fragmented adventure that could take place simultaneously in multiple communities and through different intermediaries. ${ }^{84}$ These multiple communities could have different anchors: shared concerns (e.g., saving the tropical forests), common identities (gender issues), or common business interests (shareholders). The concept of direct deliberation thus circumvents the various difficulties associated with the idea of global federalism. Furthermore, this fragmented view of the political experience fits nicely with the decentralized nature of contemporary global law, which knows no "universal center." 85

The idea of direct deliberation as a legitimization strategy builds on two different (and not necessarily interdependent) interpretations of the link between democracy and legitimacy. The first interpretation links the idea of legitimacy to the capacity of collective deliberation to produce--through the power of the "better argument"-inter-subjective agreement (and hence, consent). The second interprets the legitimizing force of the democratic process as a cultural construct, as a product of a widely-shared belief in the legitimacy of decisions that were made through a fair and society-wide dialogue. Whereas the first account attributes the legitimization force of the democratic process to its capacity to

82. Joshua Cohen \& Charles Sabel, Directly-Deliberative Polyarchy, 3 Eur. L.J. 313, 314 (1997), available at http://www.law.columbia.edu/sabel/papers/ddp.html.

83. Id. at 337; see also Michael C. Dorf \& Charles F. Sabel, $A$ Constitution of Democratic Experimentalism, 98 Colum. L. Rev. 267 (1998).

84. See David Goldblatt, Review at the Limits of Political Possibility: The Cosmopolitan Democratic Project, 225 New Left Rev. 140, 146 (1997); see also Regulating Globalization?, supra note 63, at 400 . Held notes in that context that a "democratic political community for the new millennium necessarily describes a world where citizens enjoy multiple citizenships." Id. at 402 .

85. The idea that international society would develop multiple legal centers instead of a single "Supreme Court" has not received enough attention in the legal literature. See, e.g., Roscoe Pound, Address at the Fletcher School of Law and Diplomacy, Tufts College, A World Legal Order: Law and Laws in Relation to World Law 41-42 (1959); see also Richard Falk, A New Paradigm for International Legal Studies: Prospects and Proposals, in International Law: A Contemporary PerspecTive 651 (Richard Falk et al. eds., 1985). 
produce argument-based consent, the second associates this force to the cultural standing of the democratic ethos. ${ }^{86}$

From the perspective of directly deliberative democracy, the only feasible response to the democratic challenge of the new transnational law lies, then, in the development of novel arenas for deliberation, which could break the mold of the current nationalistic order and offer a realistic alternative to the utopian model of global federalism. This pragmatic agenda raises two distinct questions. First, to what extent is the vision of directly deliberative democracy marred by practical difficulties? Second, is the response of the direct-deliberation school to the question of the democracy-legitimacy linkage really convincing? The first question is considered below, the second in Part IV.

\section{The Internet as a Global Deliberative Medium}

The practical dilemma posed by the idea of global deliberation can be stated quite simply: is there a feasible institutional structure/design which could enable the global civic society to review, scrutinize, and participate in the game of transnational norm production? The Internet, with its ability to cut time and space barriers, has been identified by many observers as the only medium through which the vision of transnational democracy might be realized.$^{87}$ The following section seeks to examine this argument more closely.

The advantage of the Internet as a medium for deliberation lies in its capacity to support multi-directional communication that is not limited by geographical boundaries. The term "multi-directional communication" refers to communication processes in which all the participants share similar influence over the subject

\footnotetext{
86. For the importance of fairness in the legitimacy of supranational adjudication, see, e.g., Howse, supra note 44 , at $42-51$.

87. For example, the Financial Times argued that the "nature of civil disobedience is being irrevocably transformed by the Internet and modern communications." The Changing Face of Protest, Fin. Times, July 31/Aug. 1, 1999, at 12; see also Geoffrey Nunberg, Will the Internet Always Speak English?, AM. Prospect, Mar. 27-Apr. 10, 2000, available at http://www.prospect.org/print/v11/10/ nunberg-g.html (noting that the "forums of the Internet undoubtedly create the opportunity for a wider and more participatory public discourse than has ever before been possible"); Paul Starr, The Electronic Commons, Am. Prospecr, Mar. 27-Apr. 10, 2000, available at http:/www.prospect.org/print/v1 1/10/starr-p.html.
} 
matter, time, and speed of communication. ${ }^{88}$ This concept envisions the electronic domain as a non-hierarchical environment, one that is not controlled by a central authority and that provides all participants with an equal opportunity to initiate and influence the conversation. ${ }^{89} \mathrm{~A}$ multi-directional communication process could be achieved by various mechanisms, such as e-mail, discussion forums, chat rooms, e-newsletters, and comprehensive e-archives. ${ }^{90}$

Despite the undeniable advantages of the Internet, using it as a vehicle for democratization is fraught with difficulties. ${ }^{91}$ First, shifting the deliberation process to the electronic domain does not in itself guarantee the emergence of an actual participatory community, because it does not resolve the basic collective action dilemma that characterizes any political action. This collective action dilemma arises because the participants in a transnational deliberative process contribute, in effect, to the production of a public good (e.g., a new normative structure) whose benefits accrue to the transnational community as a wholeincluding those members who did not bother to participate in the deliberative process. ${ }^{92}$ This "free-rider" dilemma is further exacerbated by the broad opportunities for political and non-political action on the Internet, which extend the allure of "free-riding." The immensity of the Internet could thus have a crippling effect on the capacity of society to generate e-political action.

This pessimistic prognosis is supported by the extensive psychological research, done over the last few years, on the question of spontaneous provision of public goods..$^{93}$ This research indicates that a large and scattered collection of individuals who have little sense of collective identity constitutes a poor basis for

88. I draw here on the discussion of communication and digital democracy in Jan van Dijk, Models of Democracy and Concepts of Communication, in Digital Democracy: Issues of Theory \& PracTice 30, 45-48 (Kenneth L. Hacker \& Jan van Dijk eds., 2000) [hereinafter Digital Democracy].

89. The interactive feature of the Internet distinguishes it from the traditional uni-directional broadcasting technologies, such as television or radio.

90. These different mechanisms enable both the facilitation of collective dialogue and the creation of group memory. See van Dijk, supra note 88, at 42-44.

91. For an even more skeptical view of e-democracy, see Neil Weinstock Netanel, Cyberspace 2.0, 79 TEx. L. Rev. 447, 456-59 (2000).

92. This account of the collective action dilemma is in the tradition of Mancur Olson. For a recent overview of Olson's work, see Iain McLean, Review Article: The Divided Legacy of Mancur Olson, 30. J. Pol. Sci., 651-68 (2000).

93. For a survey of this research, see Andrew M. Colman, Game Theory and Its Applications in the Social and Biological Sciences, 215-21 (1995); see also Toshio Yamagishi \& Karen S. Cook, Generalized Exchange and Social Dilemmas, 56 Soc. Psych. Q. 235 (1993). 
the emergence of spontaneous cooperation. Mechanizing political actionthrough various technologies from sophisticated filtering programs to automated "democratic" agents - might cut the opportunity costs of participation, and thus resolve part of the free rider problem. Using these automated intermediaries, however, might contaminate the deliberation process. Technological intermediaries are not neutral agents - they are products of the purposive design of firms, markets, and technological fashion - and, as such, can reflect particular political or economic agendas. ${ }^{94}$

The technological advantages of the Internet cannot guarantee the emergence of global political action (even where shared global concerns do exist). This insight points to a second difficulty in using the Internet as a global political medium. To succeed, the project of electronic participation will require central coordination and continuous public investment in an electronic public space, which will provide the appropriate conditions for the evolution of public conversation. ${ }^{95}$ Private players, whether NGOs or individuals, seldom have the necessary resources to provide (at least on an exclusive basis) these types of coordination services. These services could be provided either by governments or by the private market. But the price of this central coordination is high: the deliberation process could lose its purity and become hierarchical. Whoever controls the infrastructure that supports the e-deliberation process could influence and manipulate this process in various ways. ${ }^{96}$

94. Lawrence Lessig was probably one of the first writers to point out the non-neutral nature of Internet technology. He argues that the software code, the architecture upon which the Internet operates, can serve not just as a medium for individual liberty, but also (and quite as readily) as a tool of domination and control. See Lawrence Lessig, Architecting for Control, Keynote at the Internet Political Economy Forum, Cambridge Review of International Affairs, May 11, 2000. The main problem with this new regulatory technology, Lessig argues, is that it operates unseen, wired deep within the software and hard ware we use. Id. Furthermore, it is the product of undemocratic decisions of firms and governments. I think, however, that Lessig somewhat overstates this "technological" threat. The recent technological and commercial developments in the Net-world constitute a threat to e-political action, not so much in the constraints they impose on individual liberty, but primarily in their capacity to overshadow political opportunities by offering an almost infinite horizon of non-political choices. On that point, see Netanel, supra note 91, at 471 .

95. By "central coordination" I refer to all the various actions that might be needed in order to facilitate political action on the Net. These include, for example, building a designated space in which people can exchange views and read background material, maintaining email lists of potential participants, building alert services, creating archives, and finally designing and executing the participatory process itself. See id. at 484-91.

96. Such ways include setting the agenda, determining the form of the discussion (e.g. its length, the format of the messages), managing the information resources at the site, and so forth. 
A third difficulty concerns the problem of accessibility. This problem is particularly important in the context of North/South relationships. There is currently a wide gap between Northern and Southern countries, both in terms of computer and communication facilities and in terms of the educational background needed to use these facilities. This electronic divide casts doubts on the suitability of the electronic medium to act as a "host" for global political action. The various global initiatives that have been set up recently to cope with this divide, such as the G8 "Digital Opportunity Task Force" or UNDP and Andersen Consulting's "opportunITy Initiative," are more a reflection of the depth of the problem than a sign of its forthcoming resolution. ${ }^{97}$

The practical difficulties associated with electronic democracy cast doubt on the capacity of e-deliberation projects to produce legitimacy. But these difficulties, as will be indicated below, reflect deeper theoretical difficulties.

\section{An Alternative View of "Legitimacy": The Creative Institution}

Beyond six rivers and three mountain ranges rises Zora, a city that no one, having seen it, can forget. But not because, like other memorable cities, it leaves an unusual image in your recollections. Zora has the quality of remaining in your memory point by point, in its succession of streets, of houses along the streets, and of doors and windows in the houses, though nothing in them possesses a special beauty or rarity. Zora's secret lies in the way your gaze runs over patterns following one another as in a musical score where not a note can be altered or displaced. ... But in vain I set out to visit the city: forced to remain motionless and always the same, in order to be more easily remembered, Zora has languished, disintegrated, disappeared. The earth has forgotten her. . . ${ }^{98}$

When he enters the territory of which Eutropia is the capital, the traveler sees not one city but many, of equal size and not unlike one another, scattered over a vast, rolling plateau. Eutropia is not one, but all these cities together; only one is inhabited at a time, the others are empty; and this process is carried out in

97. For more information on these initiatives, see the website of the Digital Opportunity Task Force, at http://www.dotforce.org. For a more detailed discussion of the electronic divide, see Jan van Dijk, Widening Information Gaps and Policies of Prevention, in Digital Democracy, supra note 88 , at 166.

98. Italo Calvino, Invisible Cities 15-16 (William Weaver trans., 1972) (portraying Marco Polo's reflection on his travels, as they were told by him to Kublai Khan, the great emperor of the Tartars). 
rotation... . Thus the city repeats its life, identical, shifting up and down on its empty chessboard. The inhabitants repeat the same scenes, with the actors changed; they repeat the same speeches with variously combined accents; they open alternate mouths in identical yawns. Alone, among all the cities of the empire, Eutropia remains always the same. Mercury, god of the fickle, to whom the city is sacred, worked this ambiguous miracle. ${ }^{99}$

\section{A. From Direct Deliberation to Creativity}

The vision of direct deliberation offers two competing interpretations of the association between democracy and legitimacy. The first builds on the capacity of collective reasoning to produce consensus. The second attributes the moral power of the democratic process to the cultural standing of this process. More specifically, the vision of direct deliberation stems from the existence of a widely shared belief in the legitimacy of decisions that were made through a fair and open dialogue. Both of these arguments are highly problematic, especially when they are applied to the transnational context. The consensual interpretation of the democratic ideal depends on a deep transcendental argument. This argument, which is probably best known in its Habermasian version, aspires to demonstrate how the "reflexive possibilities of language prevent the disintegration of structures of intersubjectivity." ${ }^{100}$ By recognizing the possibility of everyday communication, Habermas argues, we necessarily presuppose the possibility of an ideal speech situation, in which actors are motivated solely by the force of the better argument. The possibility of consensual political dialogue is a direct consequence of this transcendental interpretation of everyday communication. ${ }^{101}$

Habermas's political vision depends on this conceptualization of inter-subjective communication. However, there are alternative, and not less convincing, accounts of inter-subjective communication that do not follow Habermas's consensual path. Under these accounts, disagreements, misunderstandings, and

99. Id. at $64-65$

100. Michael Power, Habermas and Transcendental Arguments: A Reappraisal, 23 Phil. Soc. ScI. 26, 45 (1993).

101. For the most recent expositions of Habermas's political theory, see Jürgen Habermas, BEtween Facts and Norms: Contributions to a Discourse Theory of Law and Democracy (William Rehg trans., 1996); Jürgen Habermas, Paradigms of Law, 17 Cardozo L. Rev. 771 (1996). For further discussion of Habermas's transcendental reasoning, see Michael Power, Habermas and the Counterfactual Imagination, 17 CARDozo L. Rev.-1005, 1014 (1996). 
conflicts are equally probable results of communication; for these more skeptical observers of the modern society, cross-cultural encounters are more likely to end in "epistemic rupture" or "dialogical paralysis" than in some kind of consensus. ${ }^{102}$ Recent psychological studies provide additional support for this skeptical view of collective deliberation. These studies indicate that the unique environment of group deliberation could significantly distort the way in which the deliberation process unfolds. ${ }^{103}$

The cultural interpretation of the democratic experience is not less problematic. The cultural hypothesis attributes the legitimizing force of democratic procedures to the cultural standing of the democratic ethos. This explanation

102. See, e.g., Niklas Luhmann, Quod Omnes Tangit: Remarks on Jürgen Habermas' Legal Theory, 17 Cardozo L. Rev. 883 (1996); Niklas Luhmann, What is Communication?, 2 Comm. Theory 251 (1992); Gunther Teubner, De Collisione Discursuum: Communicative Rationalities in Law, Morality, and Politics, 17 Cardozo L. Rev. 901 (1996). Earlier writers, such as David Hume, showed similar skepticism toward the idea of "popular consent". Thus, Hume writes:

It is in vain to say that all governments are or should be at first founded on popular consent, as much as the necessity of human affairs will admit. ... I maintain that human affairs will never admit of this consent, seldom of the appearance of it; but that conquest or usurpation, that is, in plain terms, force, by dissolving the ancient governments, is the origin of almost all the new ones which were ever established in the world. And that in the few cases where consent may seem to have taken place, it was commonly so irregular, so confined, or so much intermixed either with fraud or violence that it cannot have any great authority.

David Hume, Of the Original Contract (1777), reprinted in Hume's Moral and Political Philosophy 356, 362 (Henry D. Aiken ed., 1948).

103. Thus, for example, in a recent paper, Schkade et al. study how jury deliberations depart from the median or mean of the individual judgments of the jury members. Their results indicate that the "jury-environment" tends to produce certain systemic distortions. For example, one prominent effect was to move the group further in the direction suggested by its original tendency: where the median of individual pre-deliberation judgments favored a high punishment rating, deliberation typically increased the rating of the group, and where the median of individual pre-deliberation judgments favored a low punishment rating, deliberation typically decreased the rating of the group. These results seem to indicate that there was something in the "group atmosphere," other than rational deliberation, that influenced the results of the deliberation process. See David Schkade et al., Deliberating About Dollars: The Severity Shift, 100 Colum. L. Rev. 1139 (2000). A similar phenomenon was observed by studies of group deliberation over the Internet. These studies found that e-deliberation, especially under conditions of anonymity, tends to magnify the tendency of the group (and its members) to move toward a position that is more extreme than its pre-deliberation position. This tendency has been described in psychological literature as "group polarization." See Cass R. Sunstein, Deliberative Trouble? Why Groups Go to Extremes, 110 YaLE L.J. 71, 101 (2000). 
grounds the force of the democratic narrative in some evolutionary process, rather than rational negotiation, which led to the development of a culturally-shared belief in the democratic ideal. ${ }^{104}$ This evolutionary process is in no way deterministic or universal. It is a highly contextual, path-dependent process, influenced and shaped by the historical-geographical conditions of the societies in which it is embedded. ${ }^{105}$ The pluralistic nature of the transnational domain could thus be a source of variable, and conflicting, accounts of "democracy" (e.g., what does the requirement for a "fair and society-wide dialogue" actually mean?). ${ }^{106}$ While it is probably true that today, in the beginning of the twenty-first century, the democratic ideal is more popular than ever in human history, ${ }^{107}$ there could be, and are, highly conflicting views regarding the conditions for its realization.

The fragility of the cultural and metaphysical interpretations of the linkage between democracy and legitimacy suggests that there is a need for an alternative or supplemental justification for the attempt to democratize the norm-production process at the transnational domain. This attempt should start with the recognition that a complete and consistent rationalization of the linkage between legitimacy and democracy is not attainable. This section develops such an alternative narrative, which connects the attempts to design more "democratic" social structures with the notion of "creativity" or "creative institution." To see how this concept could be used in our context, we need to examine its meaning more closely: what does it mean to say about some person or institution that he or it is creative?

104. For a more detailed exploration of this evolutionary process, see, e.g., 1 KeN Binmore, Game Theory and the Social Contract: Playing Fair (1994); 2 Ken Binmore, Game Theory and the Social Contract: Just Playing (1994).

105. See generally, e.g., Paul A. David, Why Are Institutions the 'Carriers of History'?: Path Dependence and the Evolution of Conventions, Organizations and Institutions, 5 Structural Change \& Econ. Dynamics 205 (1994).

106. This interpretative diversity reflects, among other things, the difficulties associated with the design of a fair deliberative process. The needs of governance demand that the process of deliberation conclude with a binding decision-even if all attempts to reach a consensus have failed. The challenge of designing a framework for deliberation, then, lies in the need to develop a "cutting" mechanism of some sort which, despite its non-consensual nature, could preserve the fairness and openness of the deliberation process. This is not an easy task. Consider the (realistic) possibility in which the constitutional set-up of an international organization confers upon one of its organs the (residual) power to conclude the deliberation process. How can we ensure that this residual power is not abused, thus emptying the participatory process of any real meaning?

107. See, e.g., Keohane \& Nye, supra note 14 , at 9. 
The concept of creativity designates a distinction between creativity and dullness (or uniformity). Its exploration can start, therefore, on either side. Consider, first, the notion of dullness or evenness. In Invincible Cities, Italo Calvino offers an imaginary documentation of Marco Polo's conversations with Kublai Khan, the great emperor of the Tartars, in which Marco Polo reflects on his travels in Khan's empire. ${ }^{108}$ Zora and Eutropia were two of the many cities that Marco Polo had visited. Their story sheds some light on the meaning of dullness. Zora, Marco Polo tells the emperor, is "a city that no one, having seen it, can forget. But not because, like other memorable cities, it leaves an unusual image in your recollections." ${ }^{109}$ Zora's secret "lies in the way your gaze runs over patterns following one another as in a musical score where not a note can be altered or displaced." 10 Zora excels in its static existence. However, "forced to remain motionless and always the same, in order to be more easily remembered, Zora has languished, disintegrated, disappeared. The earth has forgotten her."

The story of Zora suggests that dynamism is the key antidote for the risks of dullness. Marco Polo's account of Eutropia, however, demonstrates that dullness could be a feature of dynamic systems as well. Eutropia is "not one city but many, of equal size and not unlike one another.... [O]nly one [of these] is inhabited at a time, the others are empty; and this process is carried out in rotation." 112 Eutropia's inhabitants "repeat the same scenes, with the actors changed; they repeat the same speeches with variously combined accents; they open alternate mouths in identical yawns." 113 The city repeats its life, therefore, in an endless circle, which always ends in the same point. Eutropia's rules of transformation ensure that it will always remain the same. Its dynamism is illusive-it offers no real change.

But what does the other side of the distinction mean? I do not intend to give a complete account of creativity (or, for that matter, of dullness) in this article. ${ }^{114}$

108. Calvino, supra note 98 , at 15-16.

109. Id. at 15.

110. Id.

111. Id. at 16.

112. Id. at 64

113. Id. at 65 .

114. For that discussion, see generally Douglas Hofstadter, Fluid Concepts \& Creative Analogies: Computer Models of the Fundamental. Mechanisms of Thought (1995) [hereinafter Fluid Concepts]; Douglas Hofstadter, Metamagical Themas: Questing for the Essence of Mind and Pattern 526-46 (1985) [hereinafter Metamagical Themas]. In order to appreciate the difficulties of defining "creativity" it might be useful to see how people who are regarded as 
Rather I wish to focus on two central aspects of creativity. The first is the possession of a flexible representational framework. The term "flexible representational framework" refers to the ability of an observer to perceive an event or object simultaneously through several different perspectives that capture diverse aspects of this event or object (e.g., its use, purpose, or context). ${ }^{115}$ In other words, it refers to the capacity of an observing system to produce variable images of the same event. The second has to do with the ability of a meaning system to break out of loops of all sorts. That is, the capacity of a "thinking system" to observe itself, to identify different patterns in its activities, and to be able to cut short those patterns which become repetitive, obsolete, or just uninteresting. ${ }^{116}$

Creativity, then, refers to the ability not to be caught everlastingly in habitual patterns. It indicates a capability for challenging established categories and recasting them in new light. ${ }^{117}$ But what does it mean for a legal institution to be

highly creative have treated this idea. Consider, for example, Marc Chagall, one of the greatest painters of the 20th century. In his biography, Chagall struggles in several places with the question of creativity. Mr LIFE (Da Capoed., 1994). The result is interesting because although it sheds some light on Chagall's own creativity, it fails to provide us with a general definition of this notion. On the day he tells his father that he wants to leave home and enter a school of art, he notes: "The essential thing is art, painting, a painting different from the painting everyone does." Id. at 65 . In another place, Chagall speaks about the difficulties he had experienced in his first days at the School of Art in Petersburg, which he attended in the beginning of his career. He notes: "The truth is, I'm incapable of learning. Or rather it's impossible to teach me. ... I get nothing except by instinct. You understand? And academic theory has no hold on me." Id. at 91. Later, speaking of his life in Paris, he tells the readers of his failed attempt to sell landscape pictures, a la Corot, at the market: "I took a photograph, but the more I tried to paint like Corot, the farther I got from it and I ended a la Chagall." Id. at 107. We have, in Chagall's narrative of creativity, a paradoxical blend of differentiation, unruled instinct, and the idea of style. To some of these elements I return above.

115. See Fluid Concepts, supra note 114, at 175; see also David C. Marr, Artificial Intelligence: A Personal View, 9 Artificial Intelligence 37, 44 (1977).

116. See Metamagical Themas, supra note 114, at 532-33; see also Fluid Concepts, supra note 114 , at 313-14.

117. This aspect of creativity was captured powerfully by Henri Bergson in Introduction to Metaphysics, in Henri Bergson, The Creative Mind 224 (1946). For him, the challenge of coping with a mobile and ceaselessly changing reality requires the mind to adopt a "creative" or "intuitive" mode; that is, it

must do itself violence, reverse the direction of the operation by which it ordinarily thinks, continually upsetting its categories, or rather, recasting them. In so doing it will arrive at fluid concepts, capable of following reality in all its windings and of adopting the very movement of the inner life of things.

Id. 
creative, and how does it relate to the quest for legitimacy? Legal creativity refers, first, to the capacity of the law to produce varied images of the same event, that is, to the flexibility of its cognitive apparatus. ${ }^{118}$ But, more importantly, it refers to the rules of transformation, which govern the process of normative change. Dynamism, as Eutropia has taught us, should not be considered as a synonym for creativity. To be creative, the rules of transformation must enable the law to reinvent itself in a non-repetitive way. ${ }^{19}$ The law must be able continuously to challenge its traditional analogies, to consider them as imperfect ratios or relations. One of the virtues of creative transformation is that it defies domination and exclusion. While it cannot guarantee that one's voice will be heard, much less accepted, it can ensure that the law is not dominated by a single voice. The appeal of the notion of "creative normativity" does not depend, therefore, on particular cultural premises, or on the promise of inter-subjective rationality, but on the capacity of creative institutions to challenge habitual social structures. In a world that cherishes diversity of thought and forms of life, this competency (or virtue) could play an important role. ${ }^{120}$ Consistency, then, is not necessarily a positive virtue. ${ }^{121}$

118. This interpretation of "creativity" is, to some extent, at odds with the scientific project. If the scientific project is interpreted as a search for a single way in which to express scientific data-for example, the smallest algorithm capable of generating (and extending) a particular series of observations-it is definitely inconsistent with the quest for institutional structures that would, by their very nature, be capable of generating multiple descriptions of reality. See generally Gregory J. Chaitin, Randomness and Mathematical Proof, 232 ScI. AM. 47 (1975); Ray Solomonoff, Does Algorithmic Probability Solve the Problem of Induction?, Oxbridge Res. Rep. 97-1 (1997), available at http://world.std.com/ rjs/isis $96 . h t m l$.

119. For an account of creativity in law, see, e.g., Niklas Luhmann, The Third Question: The Creative Use of Paradoxes in Law and Legal History, 15 J. L. \& Soc'Y 153 (1988).

120. See, e.g., Charles Taylor, Multiculturalism and "The Politics of Recognition" (1992); Lawrence Blum, Recognition, Value, And Equality: A Critique of Charles Taylor's and Nancy Fraser's Accounts of Multiculturalism, 5 Constellations 51 (1998) (indicating that cultural distinctiveness is necessary to create a sense of individual value).

121. Robert Howse has considered the question of the legitimacy of the WTO adjudicative system. See Howse, supra note 44 . He argues that the values of coherence and consistency are an important source of legitimacy for any adjudicative system. Id. at 60 . This argument, as was suggested above, is highly problematic. To the extent that certain rules are perceived as fair or legitimate in and by themselves, their consistent application might be socially valuable. Consistent or coherent application, however, in itself says nothing about the legitimacy of the applied rules. Indeed, the GATT and WTO were highly consistent in their rejection of Article XX claims over the years, id. at 46-47, 68, which did not stop these rulings from being highly controversial. 
However, legal creativity has its own costs. ${ }^{122}$ Social actors in various fields, from business to politics to sports, rely on the normative framework in force, and plan their actions accordingly. In a creative legal system such reliance could never be absolute. Normative uncertainty could (although not necessarily) impose economic or mental costs on those who rely on the law. The transition to a new normative regime could also impose various adjustment costs (reflecting, for example, learning efforts or any planned or unplanned effects). These considerations are not without weight, but they do not form a convincing argument for conservatism. As Italo Calvino's story of Zora indicates, the apparent "efficiency" of legal conservatism could be illusory. Conservatism and dullness carry other risks: the risks of degeneration, decay, and disintegration. In a world that increasingly loses its faith in the existence of true descriptions (of the world, of morality), it seems that some expectation shift is inevitable. Niklas Luhmann, the prominent German sociologist, has encapsulated this point insightfully: "What would be important then would be not a potential for security but rather a potential for insecurity. And not dependence but rather freedom: the place of capriciousness that cannot find a home: imagination." 123

Attributing the virtue of creativity to institutions assumes, of course, that there is a sensible way by which institutions and humans could be distinguished-that institutions are not just aggregates of human agents. ${ }^{124}$ This distinction means, among other things, that the capacity of human beings for

122. See generally Michael P. van Alstine, The Costs of Legal Change, 49 UCLA L. Rev. 789 (2002) (exploring the cost to a legal system of adjusting to new laws).

123. Niklas Luhmann, Observations on Modernity 43 (1998).

124. The concept of "creative institution" requires us, then, to make a clear distinction between the institution - the legal system in our context-and the human (professional or other) community that takes part in its operation. Law, as an institution, is understood here as a self-reproducing, recursive network of communications, which is ordered by a unique structure based primarily on the distinction between legal and illegal. The emergence of law as a unique cultural phenomenon occurs, then, not on the basis of some organizational or professional complex, but rather through the development of unique communicative patterns. This communicative vision departs from other models of law, in which the legal system is described as either "an ordered set of propositions or an organizational system." Niklas Luhmann, The Coding of the Legal System, in State, Law and Economy as Systems: Regulation and Autonomy in a New Perspective 145, 153 (A. Febbrajo \& Gunther Teubner eds., 1992). Legal actors are not seen, therefore, as part of the legal system, but, rather, as conditions in the environment, which might indeed be indispensable to the operation of the law, but are not constitutive of it. See generally Niklas Luhmann, Operational Closure and Structural Coupling: The Differentiation of the Legal System, 13 Cardozo L. Rev. 
creative thought and behavior does not guarantee the creativity of the social institutions in which their actions are embedded. The reality is quite different: it is not only that the creativity of human beings cannot be attributed automatically to the institutions in which they operate, but that institutional structures actually pose a continuous threat to this fragile human virtue. ${ }^{125}$ The capacity of institutions to suppress and overpower human creativity provides further motivation for the development of organizational mechanisms that can support creativity.

1419 (1992). This vision of the law as a social system distinguishes sharply between the social and psychic realms. Human individuals reappear in the social world of communication, only

as communicative constructions, as semantic artifacts, that have no correspondence to consciousness, to the autopoietic processes in the psychic world. Psychic and social processes do co-exist; they are 'coupled' by synchronization and coevolution, but there is no overlap in their operations. There is norhing but a symmetry of reality constructions: psychic processes produce mental constructs of society, and social processes produce communicative constructs of the psyche.

Gunther Teubner, How the Law Thinks: Toward a Constructivist Epistemology of Law, 23 L. \& SOC'Y REV. 727, 737 (1989).

125. The Holocaust is probably the most terrible manifestation of this threat. Jean Améry provides a disturbing description of how creativity or intellect can be destroyed by institutions. JEAN Améry, At the Mind's Limits: Contemplations by a Survivor on Auschwitz and Its Realities (Sidney Rosenfeld \& Stella P. Rosenfeld trans., 1980). Améry argues that to flourish, human intellect needs a social function. This social function was absent, Améry argues, in most of the concentration camps. In Auschwitz, he writes:

the intellect was nothing more than itself and there was no chance to apply it to a social structure, no matter how insufficient, no matter how concealed it may have been. Thus the intellectual was alone with his intellect, which was nothing other than pure content of consciousness, and there was no social reality that could support and confirm it.

Id. at 6. In Auschwitz,

everything intellectual gradually took on a doubly new form: on the one hand, psychologically, it became something completely unreal, and on the other hand, to the extent that one defines it in social terms, a kind of forbidden luxury. Sometimes one experienced these new facts at deeper levels than those one can reach during a bunk-bed conversation; then the intellect very abruptly lost its basic quality: its transcendence.

Id. at 7. The dreadful social reality that was constructed by the Nazis gave no room for intellectual creativity. For further discussions of the fragility of human creativity, see FRANCISCO J. VARELA, ETHICAL KNOW-HOW: ACTION, WISDOM AND COGNITION (1999); METAMAGICAL THEMAS, supra note 114, at 526-46. 
The notion of creativity can thus be used as a basis for both justifying and criticizing transnational legal institutions. The argument, however, with respect to institutional creativity should not be understood as part of an attempt to compose a comprehensive virtue ethics for institutions. Virtue ethics, in the tradition of Aristotle, seeks to compile a list of traits that combined determine an ideal, virtuous moral type. ${ }^{126}$ This notion of virtue forms an integral part of the understanding of morality, and a point of departure for the evaluation of behavior. ${ }^{127} \mathrm{My}$ argument, in contrast, postulates the linkage between legitimacy and creativity as contingent and indefinite. The ethical or political value of creativity is contingent and remains a matter of point of view. One such point of view, pluralism, and its possible consequences, was discussed above. I do not claim, however, that this point of view has a privileged or comprehensive moral status. In that sense, creativity does not offer absolute justification for institutional authority.

\section{B. Potential Applications}

The idea of institutional creativity is not just an abstract construct. It could be used as an admittedly rough yardstick for evaluating the legitimacy of legal structures. Two examples could clarify my argument. To a large extent, the attempts to democratize the process of transnational norm production could be reinterpreted as an effort to ensure the creativity of transnational law. Consider for example the issue of NGO participation. I argued above that the idea of NGO-

126. See generally Aristotle, Nicomachean Ethics (C. J. Rowe \& Sarah Broadie trans., 2002); Heidi Li Feldman, Prudence, Benevolence, and Negligence: Virtue Ethics and Tort Law, 74 CHI.Kent L. Rev. 1431 (2000). The most influential attempt to construct a theory of law in the Aristotelian tradition is Lon Fuller, The Morality of Law (1969). As explained in the text, however, I do not follow Fuller's path.

127. As Feldman notes:

One novel feature of the virtue ethics approach is that, while it relies on character traits as a way of appraising conduct, it does not appraise actions according to the actual subjective motives or character traits of the actor. In other words, virtue ethics does not think acts inherit their moral worth from the motive of the actor. Instead, virtue ethics identifies particular traits as more or less worthy, asks what sort of acts these traits dispose a person to perform, and then rates acts according to whether or not they are of the kind a person possessed of worthy character traits would perform.

Feldman, supra note 126, at 1432. 
led democratization is problematic primarily because NGOs, by their very nature, suffer from the same democratic flaws that characterize the transnational organizations (e.g., the WTO) that they claim to democratize. It is not clear, then, why incorporating NGOs into the decisionmaking apparatus of those organizations should make them more democratic (and hence legitimate).

However, looking at this argument from the perspective of creativity endows it with a different meaning. The point of the NGO-participation argument is not to augment the WTO democratic profile, but, rather, to build up its creativity by exposing it to a variety of cognitive and normative standpoints. The procedural rules that govern the participation of NGOs in the work of the WTO should be designed, then, with this goal in mind. Any participation scheme should include two key elements. First, the scheme would have to ensure that the right of participation would be allocated to NGOs with sufficiently different political or philosophical agendas. From the perspective of creativity, there should not be an a-priori requirement to open the norm-production process to any interested party. Second, the law would have to guarantee that the NGOs' arguments would receive "fair" hearing, though how to achieve this remains a difficult problem. ${ }^{28}$

The recent discussion of the precautionary principle within the WTO provides another example of the possible role of creativity as a source of legitimacy. The precautionary principle is one of the greatest puzzles of contemporary international environmental law. Despite the fact that this principle is used extensively in legal communication, its meaning remains highly disputed. ${ }^{129}$ This vagueness has made the problem of operationalizing the precautionary principle

128. One way to ensure the goal of "fair hearing" is to require the legal tribunal to give detailed reasons for rejecting any NGO's argument. In the context of the WTO, such obligation could be anchored in the Panel's duty under Article 11 of the DSU to "make an objective assessment of the matter before it, including an objective assessment of the facts of the case and the applicability of and conformity with the relevant covered agreements. .." DSU, supra note 47, art. 11. The Appellate Body used this part of Article 11 in its Shrimp decision to justify its interpretation of the panel's wide authority to accept information from third parties. See Shrimp Report, supra note 7, II 106. The notion of "creativity" was not mentioned, however, by the Appellate Body.

129. See Kenneth R. Foster et al., Science and the Precautionary Principle, 288 Science 979 (2000), available at http://www.biotech-info.net/science_and_PP.html; see also Commission for the European Communities, Communication from the Commission on the Precautionary Principle, COM(2000) 1, Feb. 2000, available at europa.eu.int/comm/dgs/health_consumer/ library/pub/ pub07_en.pdf; Hormones Case, supra note 7. The Appellate Body rejected the attempt of the European Union to justify its ban on hormone-treated beef by reference to the precautionary principle. 
both difficult and pressing. The WTO Appellate Body had to confront this problem in a recent dispute between Japan and the United States. ${ }^{130}$ The dispute was triggered by the imposition of certain quarantine requirements by the Japanese authorities on the import of agricultural products from the United States. The Panel found that these restrictions were maintained without sufficient scientific evidence in the sense of Article 2.2 of the SPS Agreement. ${ }^{131}$ The Panel's conclusions were upheld by the Appellate Body, which recommended that Japan change its regulatory scheme and bring it into conformity with the SPS Agreement. ${ }^{132}$ Japan tried to justify its regulatory scheme by invoking Article 5.7 of the SPS Agreement, which is the SPS version of the precautionary principle. This Article reads as follows:

In cases where relevant scientific evidence is insufficient, a Member may provisionally adopt sanitary or phytosanitary measures on the basis of available pertinent information, including that from the relevant international organizations as well as from sanitary or phytosanitary measures applied by other Members. In such circumstances, Members shall seek to obtain the additional information necessary for a more objective assessment of risk and review the sanitary or phytosanitary measure accordingly within a reasonable period of time. ${ }^{133}$

While the Appellate Body did not object, in principle, to the suggestion that it should take account of general principles of international environmental law, it noted that the legal status of the precautionary principle is still an open question, and that the appeal was not the proper place to resolve it. Id. Il 123.

130. Appellate Body Report, Japan-Measures Affecting Agricultural Products, WT/DS76/AB/R, Feb. 22, 1999, available at http:/www.wto.org/english/tratop_e/dispu_e/542d.pdf [hereinafter, Japan AB Report].

131. Panel Decision, Japan-Measures Affecting Agricultural Products, WT/DS76/R, Oct. 27, 1998, I 8.43, available at http://www.wto.org/english/tratop_e/dispu_e/76r.pdf. The Panel found that the United States had raised a presumption that Japan's regulatory requirement was maintained without sufficient scientific evidence and that this presumption has not been sufficiently rebutted by Japan. Id. If 8.42 . The subject of the dispute was a "varietal testing requirement" that required, as a condition for an import license, a separate testing for each variety of any agricultural product that was subject to a general quarantine treatment requirement. The varietal requirement was applied even if the quarantine treatment was found to be effective with respect to other varieties of the same product. The Japanese measure created substantial difficulties for U.S. farmers (e.g., in the apples, cherries and walnuts sectors). See id. Il 4.20, tbl. 2.

132. Japan AB Report, supra note 130, II $84-85$, 143-44.

133. SPS Agreement, supra note 20 , art. 5.7. 
In its discussion of Japan's arguments, the Appellate Body focused on the procedural requirements of the second sentence of Article 5.7. ${ }^{134}$ Article 5.7's second sentence establishes simple procedural requirements, under which a Member State may not maintain a provisional or precautionary sanitary or phytosanitary measure unless it: (1) "seek[s] to obtain the additional information necessary for a more objective assessment of risk;" and (2) "review[s] the ... measure accordingly within a reasonable period of time." 135

These two requirements can be seen as setting the basis for creative or reflexive regulation. They seek to create an environment of "constant reflection," which will discourage normative rigidity. ${ }^{136}$ In rejecting the Japanese attempt to rely on the precautionary principle, the Appellate Body pointed to the fact that Japan has failed to meet both of these procedural requirements. ${ }^{137}$ In judging the regulatory regimes of its Members, the WTO legal system looks, then, not just to the normative content of these regimes, but also to the capacity of these regulatory regimes to generate "normative creativity."

\footnotetext{
134. Japan AB Report, supra note 130, 11 11-14. In this way, the Appellate Body sought to circumvent the more difficult question of the meaning of the two somewhat inconsistent requirements of Article 5.7. The first sentence of Article 5.7 refers, on the one hand, to the scarcity of the current "scientific evidence," and on the other hand, requires that the sanitary measures be based, nonetheless, on "available pertinent information." Reconciling these dual requirements is not an easy task. This problematic tension is inherent in implementation of the precautionary principle. Since complete scientific certainty is the exception, rather than the norm, it is not clear how using the "precautionary principle" should actually change the nature of regulatory decisionmaking. See U.S. Mission to the European Union, U.S. Government Submission to the Committee on General Principles of the Codex Alimentarius Commission for the Committee's Apr. 10-14, 2000 Meeting: Working Principles for Risk Analysis, Mar. 22, 2000, para. 5, at http://www.useu.be/issues/ confdoc0322.html.

135. SPS Agreement, supra note 20, art. 5.7.

136. Normative rigidity is one of the indications of protectionist intent.

137. Japan AB Report, supra note 130, II 92-93. The Panel noted, in that context, that the varietal testing requirement had been in place since 1969, and was first applied to the relevant U.S. products in 1979. Japan had, therefore, almost 30 years within which it could have gathered data on the scientific justification of the varietal testing requirement. Id. If 8.57. This fact was important even though the obligation "to review" the SPS measure has only been in existence since January I, 1995. The Appellate Body noted, further, that since Japan's varietal testing requirement failed to meet the requirements of the second sentence of Article 5.7, there was no need to examine whether it failed to meet the requirements of the first sentence of Article 5.7. Id. I 91.
} 


\section{Conclusion}

The concept of "creative institution" does not claim to offer a complete account of legitimacy. Rather, it constitutes an additional perspective for viewing and articulating the idea of legitimate governance. Thus, for example, the calls for deeper involvement of NGOs in the judicial processes within the WTO, and the attempts to develop new, electronically oriented modes of participation can be seen as attempts to design more creative legal structures. Similarly, the Appellate Body's interpretation of the precautionary principle seems to ground the legitimacy of risk regimes in the reflexivity of the underlying regulatory structure. The legitimizing power of these procedural mechanisms depends, ultimately, on their capacity to challenge the habitual patterns of the domains in which they operate.

Creativity, however, is not a synonym for legitimacy. These two terms are not linked together in an inevitable path of logical necessity. The social appeal of the idea of creativity lies in the way in which it defies domination and exclusion. To the extent that this defiance is valued by society, the notion of creativity could be used as a ground for both justifying and criticizing transnational legal institutions. Creativity, however, even when it exists, cannot serve as an absolute justification for authority. Using it should, however, enrich the discourse of legitimacy. In that sense, the notion of creativity constitutes one of the pieces of which the (vague, composite) notion of legitimacy is comprised. 